\title{
Analiza Statusu Organizacji Pożytku Publicznego [OPP]. Stowarzyszenie Niezależne Zrzeszenie Studentów Uniwersytetu WROCŁAWSKIEGO [NZS UWR] JAKO JEDNOSTKA PLANUJĄCA UZYSKANIE STATUSU OPP - ANALIZA SWOT
}

\author{
Anna Maciąg, email: anna.maciag.93@gmail.com \\ Uniwersytet Wrocławski \\ Pl. Uniwersytecki 1, 50-137 Wrocław
}

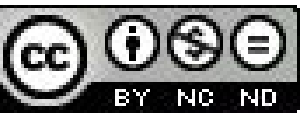

\section{STRESZCZENIE}

Status Organizacii Pożytku Publicznego został szczegółowo określony w przepisach ustawy z dnia 24.04.2003 r. o działalności pożytku publicznego i wolontariacie. Na ich podstawie przedstawiono, kto może zyskać taki status, jakie będzie miał z tego korzyści (m.in. zwolnienia podatkowe)i obowiązki (np. sprawozdawcze).

Po przeanalizowaniu przepisów ocenione zostało - z wykorzystaniem dwóch analiz SWOT - czy i kiedy Niezależne Zrzeszenie Studentów Uniwersytetu Wrocławskiego może uzyskać status OPP, a także jakie dla jego działalności niesie on przywileje, a jakie zobowiązania.

Słowa kluczowe: Niezależne Zrzeszenie Studentów Uniwersytetu Wrocławskiego, NZS UWr, status Organizacji Pożytku Publicznego.

Analysis of the Status of Public Benefit Organisation. Independent Students' Association University of Wroclaw [called NZS UWr] as a unit planning to gain the status - SWOT Analisys.

\section{Abstract}

Status of Public Benefit Organisation is specifically defined in the act of 24 April 2003 about public benefit and volunteering. Provisions of the act represent: which organizations can gain the status, what benefits they may have (eg. tax exemptions) and what duties are related to the status.

After analyzing the regulations will be assessed if and when the Independent Students' Association University of Wroclaw may acquire the status of Public Benefit Organisation and what rights and obligations are related to that status on the case.

Key words: Independent Students' Association University of Wroclaw, NZS UWr, NGO, non-govermental organisations.

\section{WSTĘP}

Status Organizacji Pożytku Publicznego [dalej zwany statusem OPP] to pojęcie wynikające z ustawy z dnia 24 kwietnia 2003 r. o działalności pożytku publicznego i wolontariacie ${ }^{1}$ [dalej jako u.d.p.p.w.]. Odnosi się ono do organizacji pozarządowych, tzw. trzeciego sektora-NGOsów² a więc instytucji działających na rzecz obywateli, dobroczynności, danych społeczności, itd. Nazwa "III sektor" wskazuje, iż ich działalnośćzasadniczo nie jest związana ani z administracją rządową (państwową), ani z samorządem. Owszem, pojedyncze podmioty są tworzone na potrzeby ww. jednostek (np. fundacje Skarbu Państwa), niemniej - to marginalne podmioty.

Wraz z rozwojem demokratycznego państwa prawa oraz realizacją konstytucyjnej wolności zrzeszania się̧, działalność na rzecz społeczeństwa staje się coraz powszechniejsza. Szczególnie jest to zauważalne pomiędzy styczniem a kwietniem, kiedy to miasta i media stale zwracają uwagę na możliwość przekazania $1 \%$ na te organizacje, które posiadają status OPP.

Przedstawienie ustawowego pojęcia OPP, wskazanie jednostek, które mogą się starać o bycie OPP wraz z wyliczeniem obowiązków i uprawnień, jakie się z nim wiąża, zajmą dużą część niniejszego artykułu. Niezbędna wiedza teoretyczna

1 Ustawa z dnia 24.04.2003 r. o działalności pożytku publicznego i wolontariacie (Dz. U. z 2014 r., poz. 1118, 1138 i 1146).

2 Ang. non-govermental organisations.

3 Art. 2 i art. 58 ust. 1 Konstytucji Rzeczpospolitej Polskiej z dnia 2 kwietnia 1997 r. (Dz. U. Nr 78, poz. 483, z 2001 r., Nr 28, poz. 319, z 2006 r. Nr 200, poz. 1471 oraz z 2009 r., Nr 114, poz. 946). 
zostanie wykorzystana w części końcowej do przeanalizowania, czy dla konkretnego podmiotu korzystne będzie staranie się o jego uzyskanie oraz czy w ogóle dana jednostka ma taką prawną możliwość.

Podmiotem tym będzie stowarzyszenie Niezależne Zrzeszenie Studentów Uniwersytetu Wrocławskiego [dalej jako NZS UWr]. Wybrałam właśnie tę organizację, gdyż od maja 2014 r. piastuję funkcję Sekretarza w Zarządzie NZS UWr i zależy mi na rzetelnej i obiektywnej analizie ww. kwestii w kontekście tego podmiotu. Znam także prawne podstawy działania organizacji oraz mam dostęp do wszelkich informacji z zakresu sprawozdawczych i finansowych podsumowań działalności.

Artykuł obejmuje stan prawny na dzień 29 grudnia $2014 \mathrm{r}$.

\section{STATUS OPP - PODSTAWA PRAWNA, ZAKRES PODMIOTOWY USTAWY}

Pojęcie statusu OPP uregulowane zostało w rozdziale 3 działu II u.d.p.p.w. Zawarte tam przepisy odnoszą się do jego zakresu podmiotowego i przedmiotowego, w tym: warunków i procedury jego uzyskania oraz obowiązków, uprawnień i nadzoru OPP.

Katalog podmiotów uprawnionych do starania się o status OPP przedstawiony został $\mathrm{w}$ art. 20 ust. 1 części wprowadzającej u.d.p.p.w., odsyłając do art. 3 ust. 2, 3 pkt 1 oraz 4. Analiza ich treści wskazuje, iż do podmiotów, które mogą starać się o status należą:

1. organizacje pozarządowe, a więc zgodnie $\mathrm{z}$ art. 3 ust. 2 u.d.p.p.w. osoby prawne oraz jednostki organizacyjne nieposiadające osobowości prawnej, które na podstawie odrębnych ustaw mają przyznaną zdolność prawna, jak chociażby fundacje i stowarzyszenia, za wyjątkiem:

- partii politycznych,

- związków zawodowych,

- organizacji pracodawców,

- samorządów zawodowych,

- fundacji utworzonych przez partie polityczne,

- $\quad$ art. 3 ust. 2 pkt 1 i 2 część wspólna u.d.p.p.w.,

- organizacji pozarządowych działających w celu uzyskania zysku,

- $\quad$ organizacji pozarządowych będących jednostkami sektora finansów publicznego, m.in. organów władzy publicznej, j.s.t, uczelni publicznych - dział I rozdział 3 ustawy z dnia 27.08.2009 r. o finansach publicznych';

2. osoby prawne i jednostki samorządu terytorialnego [dalej jako j.s.t.], na podstawie przepisów związanych ze stosunkami państwa polskiego i kościołów i związków wyznaniowych, o ile ich cele statutowe obejmują prowadzenie działalności pożytku publicznego;

3. stowarzyszenia j.s.t.;

4. spółdzielnie socjalne;

5. S.A., spółki z 0.o. oraz kluby sportowe, będące spółkami w rozumieniu przepisów ustawy z dnia 25.06.2010 r. o sporcie ${ }^{5}, 0$ ile działają nie w celu osiągnięcia zysku, a dochody przeznaczają na realizację celów statutowych.

Poza znalezieniem się wśród ww. podmiotów należy łącznie spełnić następujące przesłanki (art. 20 ust. 1 pkt 1-6 oraz 2, art. 22 ust. 1):

1. prowadzenie działalności pożytku publicznego wyłącznie na rzecz ogółu społeczności', np. studenckiej lub określonej grupy podmiotów, o ile grupa ta jest wyodrębniona ze względu na szczególnie trudną sytuację materialną lub życiową w stosunku do społeczeństwa (w przypadku stowarzyszeń działalność nie może być prowadzona wyłącznie na rzecz członków stowarzyszenia). Wyłączność oznacza tutaj zgodność statutowych celów i środków ich realizacji z katalogiem wprost określonym w ustawie (art. 4 ust. 1 u.d.p.p.w);

2. prowadzenie działalności gospodarczej jedynie jako dodatkowej w stosunku do działalności pożytku publicznego;

3. przeznaczanie nadwyżki przychodów nad kosztami na działalność, o której mowa w pkt 1;

4. posiadanie statutowego organu kontroli lub nadzoru, np. Komisji Rewizyjnej, odrębnego od organu zarządzającego, np. Zarządu, i niepodlegającego mu w zakresie wykonywania kontroli wewnętrznej/nadzoru. Członkowie tego organu:

4 Ustawa z dnia 8.11.2013 r. o zmianie ustawy o finansach publicznych oraz niektórych innych ustaw, (Dz. U. z 2013 r., poz. 885, 938 i 1646 orazz 2014 r., poz. $379,911,1146$ i 1626$)$.

5 Ustawa z dnia 25.08.2014 r. o sporcie (Dz. U. z 2014 r., poz. 715).

6 Zob. J. Blicharz, Ustawa o działalności pożytku publicznego i wolontariacie. Ustawa o spótdzielniach socjalnych. Komentarz, Warszawa 2012, s. 122. 
- $\quad$ nie mogą być członkami organu zarządzającego ani pozostawaćz nimi w związku małżeńskim, we wspólnym pożyciu, w stosunku pokrewieństwa, powinowactwa lub podległości służbowej,

- $\quad$ nie byli skazani prawomocnym wyrokiem za przestępstwo umyślne ścigane z oskarżenia publicznego lub przestępstwo skarbowe,

- mogą otrzymywać z tytułu pełnienia funkcji w takim organie zwrot uzasadnionych kosztów lub wynagrodzenie;

5. brak członków skazanych prawomocnym wyrokiem za przestępstwo umyślne ścigane z oskarżenia publicznego lub przestępstwo skarbowe w organie zarządzającym;

6. wprost wynikający z przepisów statutu lub innego aktu zakaz:

- udzielania pożyczek lub zabezpieczania zobowiązań majątkiem organizacji w stosunku do jej członków, członków organów, pracowników oraz jej osób bliskich (w rozumieniu ustawowym7),

- przekazywania majątku na rzecz ich członków, członków organów lub pracowników oraz ich osób bliskich na zasadach innych niż w stosunku do osób trzecich, w szczególności, jeżeli przekazanie to następuje bezpłatnie lub na preferencyjinych warunkach,

- $\quad$ wykorzystywania majątku na rzecz członków, członków organów lub pracowników oraz ich osób bliskich na zasadach innych niż w stosunku do osób trzecich, chyba że to wykorzystanie bezpośrednio wynika z celu statutowego,

- $\quad$ zakupu towarów lub usług od podmiotów, w których uczestniczą członkowie organizacji, członkowie jej organów lub pracownicy oraz ich osób bliskich, na zasadach innych niż w stosunku do osób trzecich lub po cenach wyższych niż rynkowe,

a stwierdzenie „,w statucie lub w innym akcie wewnętrznym", zgodnie z uchwałą Sądu Najwyższego z dnia 11.05 .2011 $\mathrm{r}^{8}$ rozumieć należy zawężająco, tzn. normy te muszą znaleźć się w akcie wewnętrznym najwyższej rangi. W przypadku stowarzyszenia rejestrowego ustawowo jest to - statut, a zwykłego - regulamin;;

7. nieprzerwane prowadzenie działalności przez okres co najmniej dwóch lat. Co ważne przepis mówi o prowadzeniu (materialnym) działalności, a nie formalnym funkcjonowaniu. Weryfikacja okresu może odbyć się poprzez okazanie odpowiednich sprawozdań finansowych i merytorycznych.

\section{STATUS OPP - ZAKRES PRZEDMIOTOWY USTAWY}

Powyższą analizę podmiotową należy uzupełnić o obowiązki i uprawnienia OPP, uregulowane w art. 23 - art. 27b u.d.p.p.w.

Wśród tych pierwszych szczególną uwagę należy zwrócić na obowiązek sporządzania rocznych sprawozdań: merytorycznego i finansowego na zasadach określonych w przepisach o rachunkowości ze swojej działalności (za wyjątkiem osób prawnych i jednostek organizacyjnych działających na podstawie przepisów regulujących stosunki państwa polskiego z kościołami i związkami wyznaniowymi, które sporządzają sprawozdanie jedynie z wyodrębnionej działalności pożytku publicznego) oraz podania ich do publicznej wiadomości, m.in. poprzez: zamieszczenie na swojej stronie internetowej; umieszczenie do 15 lipca roku następującego po roku, za który składane jest sprawozdanie na stronie internetowej urzędu obsługującego ministra ds. zabezpieczenia społecznego, czyli na stronie Departamentu Pożytku Publicznego, zatwierdzonych sprawozdań pod sankcją nieuwzględnienia w wykazie OPP.

Jeszcze do niedawna określony był krąg podmiotów, których sprawozdania finansowe nie podlegały obowiązkowi badania. Jednakże, w związku z nowelizacją z art. 1 pkt 2 lit. a ustawy z dnia 11.07.2014 r. o zmianie ustawy o rachunkowości ${ }^{10}$, od roku obrotowego $2014 \mathrm{~m}$.in. stowarzyszenia zostają zobligowane do prowadzenia sprawozdania zgodnie $\mathrm{z}$ ustawowymi wymogami: albo w formie wzoru wariantu kalkulacyjnego (podstawowego wzoru sprawozdania finansowego, który znany jest już przedsiębiorcom), albo w formie wzoru sprawozdania przeznaczonego dla jednostek mikro.

7 Osób, z którymi członkowie, członkowie organów oraz pracownicy organizacji pozostają w związku małżeńskim, we wspólnym pożyciu albo w stosunku pokrewieństwa lub powinowactwa w linii prostej, pokrewieństwa lub powinowactwa w linii bocznej do drugiego stopnia albo są związani z tytulu przysposobienia, opieki lub kurateli.

8 III CZP 16/05, nr 520242126 LEX.

9 Art. 9 i art. 40 ust. 2 ustawy z dnia 1989 r. - Prawo o stowarzyszeniach (Dz. U. z 2001 r. Nr 79, poz. 855, z 2003 r. Nr 96, poz. 874, z 2004 r. Nr 102 , poz. 1055, z 2007 r. Nr 112, poz. 766 oraz z 2011 r. Nr 112, poz. 654).

10 Ustawa z dnia 11.07.2014 r. o zmianie ustawy o rachunkowości,(Dz. U, poz. 1100). 
W przypadku organizacji pożytku publicznego, które w danym roku obrotowym osiągnęły przychód nieprzekraczający 100 tys. zł, na stronie zamieszczone zostaje sprawozdanie merytoryczne $\mathrm{w}$ formie uproszczonego sprawozdania merytorycznego, zgodnie ze wzorem określonym w rozporządzeniu Ministra Pracy i Polityki Społecznej z dnia 12 lutego 2013 r. w sprawie wzorów rocznego sprawozdania merytorycznego oraz rocznego uproszczonego sprawozdania merytorycznego z działalności organizacji pożytku publicznego ${ }^{11}$.

Poza obowiązkami sprawozdawczymi trzeba pamiętać także o solidarnej odpowiedzialności członków organu zarządzającego, organu kontroli/nadzoru OPP, którzy to odpowiadają za szkody wyrządzone (przez siebie) zawinionym działaniem lub zaniechaniem, sprzecznym z prawem bądź postanowieniami statutu (art. 27b u.d.p.p.w.).

Po przeciwnej stronie obowiązków znajduje się rozbudowany katalog uprawnień. W zakresie zwolnień z opłat i podatków art. 24 u.d.p.p.w. mówi o: podatku od osób prawnych, od nieruchomości, od czynności cywilnoprawnych oraz opłaty skarbowej i sądowej w zakresie prowadzonej działalności pożytku publicznego i na zasadach określonych w odrębnych przepisach, czyli w:

- $\quad$ art. 17 ust. 1 pkt 6c ustawy z dnia 15.02.1992 r. o podatku dochodowym od osób prawnych ${ }^{12}$ - zwolnienie z opodatkowania dochodów takiej organizacji w części przeznaczonej na działalność statutowa, z wyłączeniem działalności gospodarczej;

- $\quad$ art. 8 pkt 2a ustawy z dnia 9.09.2000 r. o podatku dochodowych od czynności cywilnoprawnych ${ }^{13}-$ zwolnienie $^{2}$ z podatku od czynności cywilnoprawnych w ramach nieodpłatnej działalności pożytku publicznego;

- $\quad$ art. 7 ust. 1 pkt 14 ustawy z dnia 12.01.1991 r. o podatkach i opłatach lokalnych ${ }^{14}$-zwolnienie od podatku w stosunku do nieruchomości lub ich części zajętych na prowadzenie nieodpłatnej działalności pożytku publicznego;

- $\quad$ art. 7 pkt 4 ustawy z dnia 16.11.2006 r. o opłacie skarbowej ${ }^{15}$ - zwolnienie w przypadku dokonywania zgłoszenia lub składania wniosku o dokonywanie czynności urzędowej, czy też wydania zaświadczenia, zezwolenia, ale wyłącznie w związku nieodpłatną działalnością pożytku publicznego;

- $\quad$ art. 104 ust. 1 ustawy z dnia 28.07.2005 r. o kosztach sądowych w sprawach cywilnych ${ }^{16}$-zwolnienie od kosztów sądowych w sprawach nie związanych z prowadzoną działalnością gospodarczą. W tym przypadku takim zwolnieniem objęte są również organizacje pozarządowe i podmioty z art. 3 ust. 3 u.d.p.p.w. w sprawach, dotyczących realizacji zadania publicznego, wynikającego z ww. ustawy.

Utrzymując się w tematyce opodatkowania, warto zwrócić uwagę na szczególny przywilej w stosunku do organizacji o statusie OPP, jakim jest możliwość otrzymywania 1\% podatku dochodowego od osób fizycznych i wydatkowania uzyskanych środków na prowadzenie działalności pożytku publicznego (art. 27 ust. 1 i 2 u.d.p.p.w.). Wykaz uprawnionych podmiotów tworzony jest na dzień 30 listopada roku podatkowego. Art. 45c ustawy z dnia 26.07.1991 r. o podatku dochodowym od osób fizycznych ${ }^{17}$ oraz art. 21b ustawy z dnia 20.11.1998 r. o zryczałtowanym podatku dochodowym od niektórych przychodów osiaganych przez osoby fizyczne ${ }^{18}$ doregulowuja, iż warunkiem niezbędnym do przekazania deklarowanego $1 \%$ podatku na organizację o statusie OPP jest złożenie zeznania podatkowego w oznaczonym terminie (za art. 45 - do 30 kwietnia roku następującego po roku podatkowym), a w przypadku korekty zeznania - musi być ona dokonana w ciągu maksymalnie miesiąca od upływu terminu na składanie zeznań podatkowych. Zapłata pełnej kwoty wynikającej z zeznania podatkowego powinna zostać uregulowana do dwóch miesięcy po dniu upływu terminu na składanie zeznania podatkowego. Darowizna przekazana zostanie pomiędzy majem a lipcem następującym

11 Rozporządzenie Ministra Pracy i Polityki Społecznej z dnia 12.02.2013 r. w sprawie wzorów rocznego sprawozdania merytorycznego oraz rocznego uproszczonego sprawozdania merytorycznego z działalności organizacji pożytku publicznego, (Dz. U., poz. 234).

12 Ustawa z dnia 15.02.1992 r. o podatku dochodowym od osób prawnych, (Dz. U. z 2014 r., poz. 851, 915, 1138, 1146, 1215 1328, 1457, 1563 i 1662).

13 Ustawa z dnia 9.09.2000 r. o podatku dochodowych od czynności cywilnoprawnych, (Dz. U z 2010 r., Nr 101, poz. 649, Nr 149, poz. 996 oraz Nr 229, poz. 1496).

14 Ustawa z dnia 12.01 .1991 r. o podatkach i opłatach lokalnych, (Dz. U. z 2014 r. poz. 849).

15 Ustawa z dnia 16.11.2006 r. o opłacie skarbowej, (Dz. U. z 2014 r., poz. 1628 i 1741).

16 Ustawa z dnia 28.07.2005 r. o kosztach sądowych w sprawach cywilnych, (Dz. U. z 2014 r., poz. 1025, 1296 i 1306).

17 Ustawa z dnia 26.07.1991 r. o podatku dochodowym od osób fizycznych, (Dz. U. z 2012 r., poz. 361, 362, 440, 596, 769, 1278, 1342, 1448, 1529 i 1540 , z 2013 r., poz. 888, 985, 1036, 1278, 1304 i 1717 oraz z 2014 r., poz. 223, 312, 567, 598, 773, 915, 1328, 1563, 1644 i 1662 ).

18 Ustawa z dnia 20.11.1998 r. o zryczałtowanym podatku dochodowym od niektórych przychodów osiaganych przez osoby fizyczne, (Dz. U. Nr 144, poz. 930, z 2000 r. Nr 74, poz. 784, Nr 88, poz. 961, Nr 104, poz. 1104 i Nr 122, poz. 1324, z 2001 r. Nr 125, poz. 1363 i 1369 i Nr 134, poz. 1509, z 2002 r. Nr 141, poz. 1183, Nr 169, poz. 1384 i Nr 200, poz. 1679, z 2003 r. Nr 43, poz. 391, Nr 96, poz. 874, Nr 135, poz. 1268, Nr 137, poz. 1286 i Nr 202, poz. 1958 , z 2004 r. Nr 210, poz. 2135 i Nr 263, poz. 2619, z 2005 r. Nr 143, poz. 1199, Nr 164, poz. 1366 i Nr 169, poz. 1420, z 2006 r. Nr 183, poz. 1353 i Nr 217, poz. 1588, z 2008 r. Nr 141, poz. 888, Nr 143, poz. 894 i Nr 209 poz. 1316, z 2009 r. Nr 157, poz. 1241 i Nr 201 poz. 1541, z 2010 r. Nr 3, poz. 13, Nr 75, poz. 473, Nr 219, poz. 1442, $\mathrm{Nr} 29$, poz. 146 i Nr 226, poz. 1478, z 2011 r. Nr 106, poz. 622 i Nr 131, poz. 764, z 2012 r., poz. 1529 i 1540 oraz z 2014 r., poz. 223 , 1328 i 1563). 
po roku podatkowym, za który składane jest zeznanie podatkowe na konto bankowe wskazane przez dany podmiot.

Poza zwolnieniami podatkowymi, organizacja o statusie OPP może na szczególnych warunkach nabywać prawo do użytkowania nieruchomości będących własnością Skarbu Państwa lub j.s.t (art. 24 ust. 2 u.d.p.p.w.), a pracę w niej mogą odbywać osoby skierowane do odbycia stużby zastępczej na zasadach i w trybie określonych w przepisach odrębnych (art. 26 u.d.p.p.w.); obecnie - w ustawie z dnia 28.11.2003 r. o stużbie zastępczej ${ }^{19}$.

W zakresie działalności promocyjnej art. 26 u.d.p.p.w. przewiduje możliwość nieodpłatnego informowaniu o działalności OPP w jednostkach publicznej radiofonii i telewizji. Kwestia ta szczegółowo uregulowana została w art. 23a ustawy $\mathrm{z}$ dnia 29.12.1992 r. o radiofonii i telewizjii ${ }^{20}$, gdzie w ust. 3 zobowiązuje do wydania rozporządzenia wykonawczego w tej materii Krajową Radę Radiofonii i Telewizji. W 2011 r. obowiązek ten został dopetniony ${ }^{21}$ i w $\S 2$ ust. 3 obliguje do poświęcenia na rzecz audycji: informujących o nieodpłatnej działalności pożytku publicznego OPP nie mniej niż 30 minut tygodniowo; prezentujących kampanie społeczne dostarczone przez te organizacje nie mniej niż 9 minut w dobowym czasie nadawanie, dzieląc ten czas na określony przedziały czasowe enumeratywnie wyliczone $\mathrm{w}$ ustawie; związanych z możliwością i trybem przekazywania 1\% podatku dochodowego od osób fizycznych, pomiędzy 1 stycznia a 30 kwietnia, a więc okresie składania zeznania podatkowego, nie mniej niż 6 minut, także z podziałem tego minimalnego czasu pomiędzy określone pory nadawania.

\section{NADzór NAD OPP}

Tematyka nadzoru na OPP uregulowana została w rozdziale 4 u.d.p.p.w. Organem nadzorującym jest minister właściwy ds. zabezpieczenia społecznego w zakresie uprawnień, obowiązków i wymogów, wymienionych enumeratywnie w art. 28 ust. 1 - katalog ten obejmuje tematykę omówioną wcześniej. Minister ma prawo do zarządzenia kontroli: z urzędu lub na wniosek: organu administracji publicznej (np. wójta, burmistrza, prezydenta miasta), organizacji pozarządowej lub podmiotów z art. 3 ust. 3 u.d.p.p.w. (o czym szerzej przy okazji omawiania zakresu podmiotowego ustawy).

Natomiast przeprowadzenie jej może zostać powierzone ministrowi właściwemu ze względu na przedmiot działalności OPP bądź wojewodzie, a więc cała kompetencja została ograniczona do administracji rządowej.

Po przeprowadzeniu kontroli opracowane zostaje wystapienie pokontrolne, zawierające ocenę stanu faktycznego, w przypadku znalezienia uchybień przedstawia się termin ich usunięcia, nie krótszy niż 30 dni. Jeżeli OPP ich nie usunie, będzie uchylała się od poddania kontroli czy rażąco naruszy przepisy prawa, minister właściwy ds. zabezpieczenia społecznego może wystąpić do sądu rejestrowego o wykreślenie organizacji z rejestru (art. 31-33 u.d.p.p.w.).

\section{NZS UWR - PODSTAWY PRAWNE DZIAEANIA, RYS STRUKTURALNY}

NZS UWr to organizacja studencka działająca przy Uniwersytecie Wrocławskim. Jako jednostka terenowa podlega zwierzchnictwu Niezależnego Zrzeszenia Studentów, a od 25.09.2013 r. posiada osobowość prawną i jest zarejestrowana jako stowarzyszenie w Krajowym Rejestrze Sądowym [dalej jako KRS]. W związku z powyższym organizacja ta zobowiązana jest równocześnie stosować się - ze względu na funkcjonowanie w ramach uczelni - do Regulaminu UWr ${ }^{22}$ i ustawy z dnia 27.07.2005 r. - Prawo o szkolnictwie wyższym ${ }^{23}$; statutu Niezależnego Zrzeszenia Studentów ${ }^{24}$ oraz ustawy z dnia 1989 r. - Prawo o stowarzyszeniach, przy czym zobligowana jest do działania na podstawie i w ramach Statutu Niezależnego Zrzeszenia Studentów Uniwersytetu Wrocławskiego, uchwalonego uchwałą Walnego Zebrania Członków z dnia 18.05.2013 r.25 [dalej zwanym „statut NZS UWr"].

19 Ustawia z dnia 28.11.2003 r. o shużbie zastępczej, (Dz. U. z 2014 r., poz. 1027 i 1198).

20 Ustawa z dnia 29.12.1992 r. o radiofonii i telewizji, (Dz. U. z 2011 r. Nr 43 poz. 226, Nr 85, poz. 459, Nr 112, poz. 654, Nr 153, poz. 903 i Nr 160, poz. 963 oraz z 2012 r., poz. 1209 i 1315).

21 Rozporządzenie Krajowej Rady Radiofonii i Telewizji z dnia 29.04.2011 r. w sprawie trybu postępowania związanego z nieodpłatnym informowaniem w programach jednostek publicznej radiofonii i telewizji o prowadzonej przez organizacje pożytku publicznego nieodpłatnej działalności pożytku publicznego (Dz. U. z 2014 r., poz. 283).

22 Regulamin obowiązuje na podstawie Zarządzenia Nr 92/2014 Rektora Uniwersytetu Wrocławskiego z dnia 15.07.2014 r. w sprawie wprowadzenia Regulaminu rejestracji, działania, finansowania, rozwiązywania uczelnianych organizacji studenckich i doktoranckich oraz stowarzyszeń w Uniwersytecie Wrocławskim, źródło: (http://www.uni.wroc.pl/studenci/dzia\%C5\%82alno\%C5\%9B\%C4\%87-studencka/doktorancka/k0\%C5\%82a-naukowe/regulamin).

23 Ustawa z dnia 27.07.2005 r., Prawo o szkolnictwie wyższym,(Dz. U. z 2012 r., poz. 572, 742 i 1544, z 2013 r., poz. 675, 829, 1005, 1588 i 1650 oraz z 2014 r., poz. 7, 768, 821, 1004, 1146 i 1198).

24 (http://www.nzs.org.pl/o-nzs/statut-nzs.html).

25 Statut Niezależnego Zrzeszenia Studentów Uniwersytetu Wrocławskiego, uchwalony uchwałą Walnego Zebrania Członków z dnia 18.05.2013 r.: (http://nzs.uni.wroc.pl/wp-content/uploads/2013/10/Statut-NZS-UWr1.pdf). 


\section{NZS UWR - PRZESŁANKI ZAKRESU PODMIOTOWEGO STATUSU OPP}

Zamieszczone poniżej informacje w sposób odpowiedni odnoszą się do ww. przesłanek podmiotowych uzyskania statusu OPP.

NZS UWr jest stowarzyszeniem rejestrowym, a więc posiadającym osobowość prawna, co potwierdza §2 statutu NZS UWr i możliwość odnalezienia organizacji w KRSie pod numerem 0000478259. Zgodnie z §8 ust. 1 statutu NZS UWr prowadzi działalność na rzecz społeczności studenckiej, czym wyczerpuje ustawowy formalny wymóg w tej kwestii. W zakresie zgodności statutowych celów i środków ich realizacji treści z $\$ 9$ i $§ 10$ ust. 1 statutu NZS UWr zawierają się w ustawowym katalogu, aczkolwiek nie są literalnym ich odwzorowaniem.

Spośród organizowanych projektów wystarczy wymienić chociażby promowanie honorowego krwiodawstwa poprzez cykliczne zbiórki krwi (pn. Wampiriada); rozwijanie umiejętności zawodowych żaków poprzez proponowanie bezpłatnych szkoleń i warsztatów z zewnętrznymi firmami w akcji Drogowskazy Kariery czy organizowanie przeglądu studenckich kapel rockowych w ramach Akademickiego RocKa. Działania te materialnie potwierdzaja, że prowadzona jest aktywność nastawiona na społeczność akademicką. Stowarzyszenie nie prowadzi działalności gospodarczej.

Działania członków i Zarządu NZS UWr kontrolowane są przez Komisję Rewizyjna, będącą organem niezależnym, wybieranym przez Walne Zebranie Członków i tylko przed nią odpowiadające za swoje czyny. Członkowie Komisji Rewizyjnej nie są jednocześnie członkami Zarządu; nie pozostają z nimi w związku małżeńskim, we wspólnym pożyciu, w stosunku pokrewieństwa, powinowactwa lub podległości służbowej; nie byli skazani prawomocnym wyrokiem za przestępstwo umyślne ścigane z oskarżenia publicznego lub przestępstwo skarbowe. Wśród członków Zarządu NZS UWr nie ma osób skazanych prawomocnym wyrokiem za przestępstwo umyślne ścigane z oskarżenia publicznego lub przestępstwo skarbowe.

Pozostają jedynie kwestie: braku w statucie NZS UWr zapisów o zakazach ze sfery dysponowania majątkiem (zmian w tym zakresie dokonać może Walne Zebranie Członków podczas swoich obrad) oraz prowadzenia nieprzerwanie działalności przez okres co najmniej dwóch lat. NZS UWr działa już na Uniwersytecie od wielu lat, jedynie dopiero z dniem 25.09.2013 r. uzyskało osobowość prawną i stało się stowarzyszeniem rejestrowym. Poza tym, jako organizacja studencka, funkcjonuje pomiędzy październikiem (a nawet II połową września) a czerwcem, stąd działania zasadniczo trwają przez 9,5-10 miesięcy w roku. Owszem, w trakcie lipca czy sierpnia zdarza się podejmować niezbędne czynności, ale nie jest to działalność statutowa. Można uznać, że ustawowe 2 lata miną dopiero w marcu 2016 r., choć zgodnie z kalendarzem będzie to pod koniec września $2015 \mathrm{r}$. Ocena czy spełniony jest ten wymóg zależy od właściwego sądu rejonowego. Lista OPP tworzona jest na dzień 30 listopada, stąd jeśli władze NZS UWr chciałyby zaryzykować, wniosek mógłby zostać złożony już w październiku. Równie dobrze może to jednak zrobić w II kwartale 2016 r.

\section{NZS UWR - PRZESEANKI ZAKRESU PRZEDMIOTOWEGO STATUSU OPP}

Tegoroczna nowelizacja w zakresie obowiązku prowadzenia sprawozdania finansowego zgodnie z przepisami o rachunkowości i tak zobowiązała stowarzyszenia do określenia, według którego wzoru będą się rozliczały. Zarząd NZS UWr uchwalił, że dla NZS UWr prowadzona będzie księgowość jak dla jednostek mikro ${ }^{26}$. Przygotowanie sprawozdania merytorycznego także nie powinno budzić wątpliwości. Już teraz jako jednostka działająca przy UWr stowarzyszenie zobowiązane jest do przygotowywania sprawozdania merytorycznego za dany rok kalendarzowy w związku z otrzymywaną dotacją na działalność od uczelni. Każdorazowe otrzymanie grantu także wymaga opracowania szczegółowego rozliczenia finansowo-merytorycznego, a koordynatorzy poszczególnych projektów zobligowani są do opracowywania raportu końcowego.

Kwestią dyskusyjnąjest dla wielu obowiązek publikowania sprawozdań. Na ten moment roczny przychód NZSUWr nie przekracza 100000 zł, stąd publikacja dotyczyłaby uproszczonego sprawozdania merytorycznego oraz sprawozdania finansowego. Warto jednak pamiętać, że takie publiczne prezentowanie swoich rozliczeń to pokazanie innym, że aktywność stowarzyszenia jest uczciwe i nastawiona na pracę na rzecz innych.

Solidarna odpowiedzialność za zawinione działania bądź zaniechania niezgodne z prawem powszechnym czy wewnętrznym nie jest czymś zupełnie nowym dla członków Zarządu NZS UWr. Już teraz, zgodnie z art. 116a Ordynacji Podatkowej27, za zaległości podatkowe stowarzyszenia odpowiadają solidarnie członkowie organu zarządzającego.

26 Uchwałą nr 02/11/2014 Zarządu Stowarzyszenia NZS UWr z dnia 27.11.2014 r. w sprawie prowadzenia ksiegowości (niepublikowana).

27 Ustawa z dnia 29.08.1997 r. Ordynacja Podatkowa (Dz. U. z 2012 r., poz. 749, 848, 1101, 1342 i 1529, z 2013 r., poz. 35, 1027, 1036, 1145, 1149, 1289, 1313 oraz z 2014 r., poz. 183, 567, 915, 1171, 1215, 1328 i 1644). 
W przypadku odpowiedzialności deliktowej kwestia jest nadal nie do końca rozstrzygnięta, jednak istnieje duże prawdopodobieństwo, iż to organ zarządzający zostałby pociągnięty do sankcji za czyny organizacji.

Spośród uprawnień dla OPP, NZS UWr w sposób szczególny skorzystałby na zwolnieniu z wybranych podatków i opłat, ze szczególnym naciskiem na opłaty sądowe, związane chociażby z uzyskaniem odpisu statutu, niezbędnego do składania wniosków grantowych. Możliwość otrzymania 1\% podatku mogłaby wesprzeć organizację finansowo i pomóc w realizacji projektów i działań na jeszcze większą skalę czy też na wyższym poziomie. Wielu ludzi ze świata polityki, rozrywki, biznesu w przeszłości działało w NZS-ach i chętnie wsparliby taki podmiot. Nie wspominającjuż o szansie na bezpłatne promowanie w telewizji i radiofonii publicznej, które dociera do licznego grona studentów - obecnych i przyszłych członków NZS-u.

\section{NADZÓR NAD NZS UWR JAKO STOWARZYSZENIEM A JAKO OPP}

Jako stowarzyszenie rejestrowe NZS UWr podlega nadzorowi starosty (art. 5 pkt 2 ustawy z dnia 7.04.1989 r. - Prawo o stowarzyszeniach), który ma prawo żądać odpisów uchwał Walnego Zebrania Członków bądź niezbędnych wyjaśnień od władz stowarzyszenia (art. 25 pkt 1 i3.). W przypadku OPP organ nadzorujący pochodzi już z administracji rządowej i jest nim minister właściwy ds. zabezpieczenia społecznego, uprawniony do zarządzenia kontroli.

W obu przypadkach organ nadzorujący zwraca się do sądu, jeżeli stowarzyszenie działa niezgodnie z prawem bądź uchyla się na ciążących na nim obowiązków. Ponadto - ze względu na byciejednostką terenową NZS-u - podlega nadzorowi Zarządu Krajowego NZS (\$25 ust. 3 pkt 3 statutu Niezależnego Zrzeszenia Studentów).

\section{NZS UWR JAKO OPP - OBOWIAZZKI KONTRA UPRAWNIENIA.}

\section{UZYSKANIE STATUSU OPP PRZEZ NZS UWr. ANALIZA SWOT}

Dla podsumowania wyżej zebranych danych, poniżej przedstawiono dwie analizy SWOT. W pierwszej ukazane zostaną wady i zalety zostania OPP. Pod poszczególnymi literami SWOT kryją się:

$\mathrm{S}$ (Strengths) - mocne strony - zalety zostania OPP - uprawnienia;

W (Weaknesses) - słabe strony - wady zyskania statutu OPP - obowiązki;

$\mathrm{O}$ (Opportunities) - szanse - zdarzenia w przyszłości, przy których łatwiej działać jako OPP;

$\mathrm{T}$ (Threats) - zagrożenia - zdarzenia w przyszłości, przy których łatwiej byłoby funkcjonować bez stausu OPP.

Tabela 1. NZS UWr jako OPP - obowiązki kontra uprawnienia

\begin{tabular}{|c|c|}
\hline \multicolumn{2}{|l|}{ NZS UWr jako OPP - obowiązki kontra uprawnienia } \\
\hline Mocne strony & Słabe strony \\
\hline $\begin{array}{l}\text { 1) Zwolnienie z podatku od osób prawnych, od } \\
\text { czynności cywilnoprawnych, od nieruchomości, } \\
\text { z opłaty skarbowej w ramach nieodpłatnej } \\
\text { działalności pożytku publicznego oraz od } \\
\text { opłaty sądowej poza działalnością w ramach } \\
\text { działalności gospodarczej. } \\
\text { 2) Uzyskiwanie darowizny z 1\% podatku } \\
\text { w ramach PIT. } \\
\text { 3) Nieodpłatne promowanie przez publiczną } \\
\text { telewizję i radiofonię. }\end{array}$ & $\begin{array}{l}\text { 1) Sporządzanie rocznego sprawozdania fi- } \\
\text { nansowego i merytorycznego z działalności } \\
\text { i publikowanie ich na swojej stronie inter- } \\
\text { netowej oraz na stronie Departamentu Pożytku } \\
\text { Publicznego. } \\
\text { 2) Solidarna odpowiedzialność członków organów } \\
\text { kolegialnych (zarządzającego, kontrolnego/ } \\
\text { nadzorczego) za zawinione i bezprawne działania } \\
\text { bądź zaniechania. } \\
\text { 3) Poddanie się pod nadzór ministra właściwego ds. } \\
\text { zabezpieczenia społecznego. }\end{array}$ \\
\hline Szanse & Zagrożenia \\
\hline $\begin{array}{l}\text { 1) Uzyskanie dotacji na niższym poziomie z uczelni } \\
\text { bądź niezdobycie grantów na projekty na skalę } \\
\text { „ogólnopolską", gdzie można zdobyć środki } \\
\text { z innych źródeł. } \\
\text { 2) Udział w konkursach grantowych czy realizacja } \\
\text { zadań publicznych, które generują koszty } \\
\text { w formie opłat sądowych za np. wyciag ze } \\
\text { statutu, a z których OPP są zwolnione. }\end{array}$ & $\begin{array}{l}\text { 1) W przypadku naruszenia prawa odpowiada się } \\
\text { przed ministrem, a nie starostą. } \\
\text { 2) Możliwość przeprowadzenia kontroli przez } \\
\text { ministra. }\end{array}$ \\
\hline
\end{tabular}

Źródło: opracowanie własne. 
W drugiej Analizie SWOT oceniona zostanie możliwości uzyskania statutu OPP przez NZS UWr, więc poszczególne litery skrótu oznaczają:

S (Strengths) - mocne strony - przesłanki podmiotowe i przedmiotowe z u.d.p.p.w. do uzyskania statusu OPP, które NZS UWr spełnia;

W (Weaknesses) - słabe strony - przesłanki podmiotowe i przedmiotowe zu.d.p.p.w. do uzyskania statusu OPP, które NZS UWr nie spełnia;

O (Opportunities) - szanse - działania, jakie NZS UWr może podjąć w celu zmian słabych stron na silne;

$\mathrm{T}$ (Threats) - zagrożenia - czynniki, które mogą wpłynąć na niemożność zmian słabych stron w mocne, bądź spowodują przejście mocnych stron na słabe.

Tabela 2. Uzyskanie statusu OPP przez NZS UWr

\begin{tabular}{|c|c|}
\hline \multicolumn{2}{|l|}{ Uzyskanie statusu OPP przez NZS UWr } \\
\hline Mocne strony & Słabe strony \\
\hline $\begin{array}{l}\text { 1) Posiadanie osobowości prawnej i kwalifikowanie } \\
\text { się do ustawowej definicji organizacji } \\
\text { pozarządowej. }\end{array}$ & $\begin{array}{l}\text { 1) Brak przepisów w statucie NZS UWr } \\
\text { zakazujących wprost dysponowania majątkiem } \\
\text { pomiędzy członkami organizacji. }\end{array}$ \\
\hline $\begin{array}{l}\text { 2) Prowadzenie działalności na rzecz społeczności } \\
\text { studenckiej i przeznaczanie nadwyżki } \\
\text { przychodów nad kosztami na ww. działalność. }\end{array}$ & $\begin{array}{l}\text { 2) Jako Stowarzyszenie rejestrowe prowadzenie } \\
\text { działalności od 25.09.2013 r., a więc krócej niż } \\
\text { nieprzerwane } 2 \text { lata działalności wymagane }\end{array}$ \\
\hline $\begin{array}{l}\text { 3) Cele i statutowe działania, mieszczące się } \\
\text { w katalogu z u.d.p.p.w. }\end{array}$ & ustawowo. \\
\hline \multicolumn{2}{|l|}{$\begin{array}{l}\text { 4) Funkcjonowanie Komisji Rewizyjnej, odrębnej od } \\
\text { Zarządu NZS UWr. }\end{array}$} \\
\hline \multicolumn{2}{|l|}{$\begin{array}{l}\text { 5) Członkowie Zarządu NZS UWr i Komisji } \\
\text { Rewizyjnej nie byliby skazani prawomocnym } \\
\text { wyrokiem za umyślne przestępstwo ściganie } \\
\text { z oskarżenia publicznego czy skarbowe. }\end{array}$} \\
\hline Szanse & Zagrożenia \\
\hline $\begin{array}{l}\text { 1) Wprowadzenie zmian do statutu przy okazji } \\
\text { najbliższego Walnego Zebrania Członków. }\end{array}$ & $\begin{array}{l}\text { 1) Brak zgody Walnego Zebrania Członków na } \\
\text { wprowadzenie zmian. }\end{array}$ \\
\hline \multirow{3}{*}{$\begin{array}{l}\text { 2)Złożenie wniosku po upływie ustawowego } \\
\text { okresu dwóch lat nieprzerwanej działalności. }\end{array}$} & 2) Zaprzestanie działalności przez NZS UWr. \\
\hline & $\begin{array}{l}\text { 3) Ograniczenie się do działania jedynie na rzecz } \\
\text { członków NZS UWr. }\end{array}$ \\
\hline & $\begin{array}{l}\text { 4) Brak zainteresowania uzyskaniem statusu OPP } \\
\text { przez kolejne organy zarządzające. }\end{array}$ \\
\hline
\end{tabular}

Źródło: opracowanie własne.

\section{ZAKOŃCZENIE}

Status OPP jest dla wielu organizacji niezbędnym elementem działalności. Ustawowa regulacja z u.d.p.p.w. obejmuje wiele podmiotów, które mogą się o niego starać, oferując liczne przywileje, związane m.in. ze zwolnieniami podatkowymi (choćby $1 \%$ podatku) i pewien zakres obowiązków, szczególnie sprawozdawczych.

Oceniając powyższe analizy SWOT i dane zebrane w całym artykule, można uznać, żę w przypadku NZS UWr zdobycie statutu OPP jest jedynie kwestią czasu. Odkąd organizacja ta została zarejestrowana jako stowarzyszenie w KRS-ie, zyskała szansę na zyskanie liczych uprawnień, których nie należy lekceważyć. NZS UWr to organizacja dysponująca niewielkim rocznym budżetem, nieprzekraczającym 50 tys zł. Koszty ponoszone w ramach opłati podatków są dosyćwysokie, a szanse na promocję poza UWr niewielkie. Zdobycie statusu OPP umożliwi działania na szerszą skalę. Owszem, obowiązki sprawozdawcze i upublicznianie wszelkich danych mogą budzić wątpliwości. Katalog przywilejów powinien jednak wymuszać przejrzystość działań. Jawność powinna być cechą zarówno działalności rządowej, samorządowej, jak i pozarządowej. Żyjąc w demokratycznym państwie prawa, wszyscy uczą się uczciwości, przejrzystości i jasności swoich działań. Na równi zobowiązane są do tego władze oraz III sektor. 
Większość ustawowych przesłanek została już spełniona przez NZS UWr. Oczywiście, może się zdarzyć, że Walne Zebranie Członków odmówi wprowadzenia zmian do statutu, ale z takim ryzykiem zawsze należy się liczyć. Cele statutowe środki ich realizacji niebędące literalnym odwzorowaniem katalogu z u.d.p.p.w. także mogą być przyczyną odrzucenia wniosku przez właściwy sąd rejonowy. Status OPP dla NZS UWr to szansa, z jakiej stowarzyszenie powinno skorzystać.

\section{Bibliografia:}

Wykaz publikacji

[1] Blicharz J., Ustawa o działalności pożytku publicznego i o wolontariacie. Ustawa o spótdzielniach socjalnych. Komentarz. Warszawa 2012

[2] Ogonowski A., Gibalska A.: Fundacje. Stowarzyszenia. Zasady funkcjonowania i opodatkowania. Kraków 2009

\section{Wykaz źródeł prawa}

[3] Konstytucja Rzeczpospolitej Polskiej z dnia 2.04.1997 r. (Dz. U. Nr 78, poz. 483, z 2001 r. Nr 28, poz. 319, z 2006 r. Nr 200, poz. 1471 oraz z 2009 r., Nr 114, poz. 946)

[4] Ustawa z dnia 7.04.1989 r. - Prawo o stowarzyszeniach (Dz. U. z 2001 r. Nr 79, poz. 855, z 2003 r. Nr 96, poz. 874, z 2004 r. Nr 102, poz. 1055, z 2007 r. Nr 112, poz. 766 oraz z 2011 r. Nr 112, poz. 654)

[5] Ustawa z dnia 12.01.1991 r o podatkach i opłatach lokalnych (Dz. U. z 2014 r. poz. 849)

[6] Ustawy z dnia 26.07.1991 r. o podatku dochodowym od osób fizycznych (Dz. U. z 2012 r., poz. 361, 362, 440, 596, 769, 1278, 1342, 1448, 1529 i 1540, z 2013 r., poz. 888, 985, 1036, 1278, 1304 i 1717 oraz z 2014 r., poz. 223, 312, 567, 598, 773, 915, 1328, 1563, 1644 i 1662)

[7] Ustawa z dnia 15.02.1992 r. o podatku dochodowym od osób prawnych (Dz. U. z 2014 r., poz.851, 915, 1138, 1146, 1215 1328, 1457, 1563 i 1662)

[8] Ustawa z dnia 29.12.1992 r. o radiofonii i telewizji (Dz. U. z 2011 r. Nr 43 poz. 226, Nr 85, poz. 459, Nr 112, poz. 654, Nr 153, poz. 903 i Nr 160, poz. 963 oraz z 2012 r., poz. 1209 i 1315)

[9] Ustawa z dnia 29.08.1997 r. - Ordynacja Podatkowa (Dz. U. z 2012 r., poz. 749, 848, 1101, 1342 i 1529, z 2013 r., poz. 35, 1027, 1036, 1145, 1149, 1289,1313 oraz z 2014 r., poz. $183,567,915,1171,1215,1328$ i 1644)

[10] Ustawa z dnia 20.11.1998 r. o zryczattowanym podatku dochodowym od niektórych przychodów osiaganych przez osoby fizyczne (Dz. U. $\mathrm{Nr}$ 144, poz. 930, z 2000 r. Nr 74, poz. 784, Nr 88, poz. 961, Nr 104, poz. 1104 i Nr 122, poz. 1324, z 2001 r. Nr 125, poz. 1363 i 1369 i Nr 134, poz. 1509, z 2002 r. Nr 141, poz. 1183, Nr 169, poz. 1384 i Nr 200, poz. 1679, z 2003 r. Nr 43, poz. 391, Nr 96, poz. 874, Nr 135, poz. 1268, Nr 137, poz. 1286 i Nr 202, poz. 1958, z 2004 r. Nr 210, poz. 2135 i Nr 263, poz. 2619, z 2005 r. Nr 143, poz. 1199, Nr 164, poz. 1366 i Nr 169, poz. 1420, z 2006 r. Nr 183, poz. 1353 i Nr 217, poz. 1588, z 2008 r. Nr 141, poz. 888, Nr 143, poz. 894 i Nr 209 poz. 1316, z 2009 r. Nr 157, poz. 1241 i Nr 201 poz. 1541, z 2010 r. Nr 3, poz. 13, Nr 75, poz. 473, Nr 219, poz. 1442, Nr 29, poz. 146 i Nr 226, poz. 1478, z 2011 r. Nr 106, poz. 622 i Nr 131, poz. 764, z 2012 r., poz. 1529 i 1540 oraz z 2014 r., poz. 223, 1328 i 1563)

[11] Ustawa z dnia 9.09.2000 r. o podatku dochodowych od czynności cywilnoprawnych (Dz. U z 2010 r., Nr 101, poz. 649, Nr 149, poz. 996 oraz Nr 229, poz. 1496)

[12] Ustawa z dnia 24.04.2003 r. o działalności pożytku publicznego i wolontariacie (Dz. U. z 2014 r., poz. 1118, 1138 i 1146)

[13] Ustawa z dnia 28.11.2003 r. o służbie zastępczej (Dz. U. z 2014 r., poz. 1027 i 1198)

[14] Ustawa z dnia 28.07.2005 r. o kosztach sądowych w sprawach cywilnych (Dz. U. z 2014 r., poz. 1025, 1296 i 1306)

[15] Ustawa z dnia 16.11.2006 r. o opłacie skarbowej (Dz. U. z 2014 r., poz. 1628 i 1741)

[16] Ustawa z dnia 27.08.2009 r. o finansach publicznych (Dz. U. z 2013 r., poz. 885, 938 1646 oraz z 2014 r., poz. 379, 911, 1146i 1626)

[17] Ustawa z dnia 25.06.2010 r. o sporcie (Dz. U. z 2014 r., poz. 715)

[18] Rozporządzenie Ministra Finansów z dnia 23.12.2004 r. w sprawie obowiązku badania sprawozdań finansowych organizacji pożytku publicznego (Dz. U. Nr 285, poz. 2852)

[19] Ustawa z dnia 27.07.2005 r. - Prawo o szkolnictwie wyższym (Dz. U. z 2012 r., poz. 572, 742 i 1544, z 2013 r., poz. 675, 829, 1005, 1588 i 1650 oraz z 2014 r., poz. 7, 768, 821, 1004, 1146 i 1198)

[20] Rozporządzenie Krajowej Rady Radiofonii i Telewizji z dnia 29.04.2011 r. w sprawie trybu postępowania związanego z nieodpłatnym informowaniem w programach jednostek publicznej radiofonii i telewizji o prowadzonej przez organizacje pożytku publicznego nieodpłatnej działalności pożytku publicznego (Dz. U. z 2014 r., poz. 283)

[21] Rozporządzenie Ministra Pracy i Polityki Społecznej z dnia 12.02.2013 r. w sprawie wzorów rocznego sprawozdania merytorycznego oraz rocznego uproszczonego sprawozdania merytorycznego z działalności organizacji pożytku publicznego (Dz. U., poz. 234)

[22] Uchwała nr 02/11/2014 Zarządu Stowarzyszenia NZS UWr z dnia 27.11.2014 r. w sprawie prowadzenia księgowości (niepublikowana)

Wykaz orzeczeń

[23] Uchwała Sądu Najwyższego z dnia 11.05.2011 r. (III CZP 16/05 nr 520242126 LEX)

\section{Netografia:}

[24] Zarządzenie Nr 92/2014 Rektora Uniwersytetu Wrocławskiego z dnia 15.07.2014 r. w sprawie wprowadzenia Regulaminu rejestracji, działania, finansowania, rozwiązywania uczelnianych organizacji studenckich i doktoranckich oraz stowarzyszeń w Uniwersytecie Wrocławskim,http://www.uni.wroc.pl/studenci/dzia\%C5\%82alno\%C5\%9B\%C4\%87-studencka/doktorancka/ko\%C5\%82a-naukowe/ regulamin, 27.12.2014

[25] Statut Niezależnego Zrzeszenia Studentów, http://www.nzs.org.pl/o-nzs/statut-nzs.html, 27.12.2014

[26] Statut Niezależnego Zrzeszenia Studentów Uniwersytetu Wrocławskiego, uchwalony uchwałą Walnego Zebrania Członków z dnia 18 maja 2013 r., http://nzs.uni.wroc.pl/wp-content/uploads/2013/10/Statut-NZS-UWr1.pdf, 27.12.2014 